\title{
Halalkalicoccus jeotgali sp. nov., a halophilic archaeon from shrimp jeotgal, a traditional Korean fermented seafood
}

\author{
Seong Woon Roh, ${ }^{1,2}$ Young-Do Nam, ${ }^{1,2}$ Ho-Won Chang, ${ }^{2}$ \\ Youlboong Sung, ${ }^{2}$ Kyoung-Ho Kim, ${ }^{2}$ Hee-Mock $\mathrm{Oh}^{2}$ and Jin-Woo Bae ${ }^{1,2,3}$ \\ ${ }^{1}$ University of Science \& Technology, 52, Eoeun-dong, Daejeon 305-333, Korea \\ ${ }^{2}$ Biological Resource Center, KRIBB, Daejeon 305-806, Korea \\ ${ }^{3}$ Environmental Biotechnology National Core Research Center, Gyeongsang National University, \\ Jinju 660-701, Korea
}

Correspondence

Jin-Woo Bae

baejw@kribb.re.kr
The genus Halalkalicoccus, belonging to the family Halobacteriaceae, has been classified within extremely halophilic Archaea and currently contains only one species, Halalkalicoccus tibetensis, which was first isolated from Lake Zabuye in China (Xue et al., 2005). The cells of strains of the genus Halalkalicoccus are coccus-shaped and mainly Gramnegative, with some cells in young cultures staining Gram-positive. We isolated another novel species of this genus from shrimp jeotgal; a traditional fermented food from Korea that is made from tiny shrimps and rock salt. After a period of fermentation, this food acquires its own distinctive taste and it is used as an additive to improve the taste of other foods (Yoon et al., 2001). In this report, we characterize strain $\mathrm{B}^{\mathrm{T}}$ and describe the identification of this novel species.

The strain, designated $\mathrm{B}^{\mathrm{T}}$, was isolated from shrimp jeotgal using the dilution plating technique. It grew slowly on medium containing $\left(\mathrm{g} \mathrm{l}^{-1}\right)$ : Casamino acids (5; Difco),

Abbreviations: PG, phosphatidylglycerol; PGP-Me, phosphatidylglycerol phosphate methyl ester; PGS, phosphatidylglycerol sulfate.

The GenBank/EMBL/DDBJ accession number for the 16S rRNA gene sequence of strain $B^{\top}{ }^{\top}$ is EFO77632. yeast extract (5; Difco), $\mathrm{MgCl}_{2} \cdot 6 \mathrm{H}_{2} \mathrm{O}$ (20), $\mathrm{KCl}$ (2), Tris (12), $\mathrm{CaCl}_{2} \cdot 2 \mathrm{H}_{2} \mathrm{O}(0.2), \mathrm{NaCl}(200)$ and in the presence of antibiotics (penicillin $\mathrm{G}$, erythromycin and cycloheximide; $100 \mu \mathrm{g} \mathrm{ml}^{-1}$ ) that are known to inhibit bacteria and eukaryotes but not Archaea (Purdy et al., 2004). The $\mathrm{pH}$ was adjusted to 7.4 and incubation was at $37{ }^{\circ} \mathrm{C}$. In the presence of antibiotics, a pure culture from the colony on the agar plate was obtained by repeated re-streaking on halophilic medium without antibiotics. Phylogenetic analysis of the $16 \mathrm{~S}$ rRNA gene sequence of strain $\mathrm{B}^{\mathrm{T}}$ and DNA-DNA relatedness analysis, using a closely related strain, indicated that this strain is novel and belongs to the genus Halalkalicoccus. Accordingly, we describe the taxonomic position of this strain by using phenotypic, genotypic and chemotaxonomic analyses. Halalkalicoccus tibetensis JCM $11890^{\mathrm{T}}$ was used as the reference strain.

Phenotypic tests were performed in accordance with the proposed minimal standards for the description of novel taxa of the order Halobacteriales (Oren et al., 1997). Oxidase activity was determined using an oxidase reagent (bioMérieux). Total lipids were extracted by using the modified method of Xin et al. (2000). Like the reference strain, strain $B 3^{\mathrm{T}}$ is non-motile, Gram-variable and can 


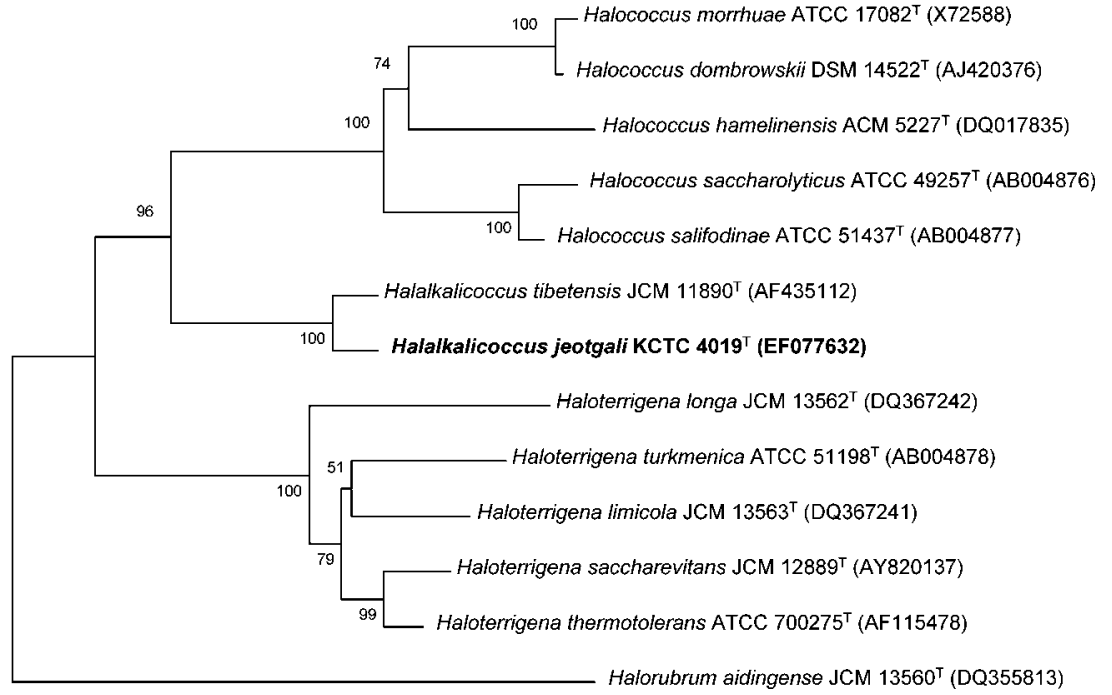

Halorubrum aidingense JCM $13560^{\top}$ (DQ355813)
Fig. 1. Neighbour-joining phylogenetic tree based on 16S rRNA gene sequences showing the position of strain $\mathrm{B}^{\top}$ with respect to other species of the genus Halalkalicoccus. Numbers at nodes indicate bootstrap values (based on 1000 replications). Bar, 0.02 substitutions per nucleotide position. utilize sucrose, glucose, lactose and acetate. Strain $\mathrm{B}^{\mathrm{T}}$, however, is oxidase-negative and cannot utilize fructose as a carbon source and cannot reduce nitrate unlike the reference strain. Polar lipid analysis indicated that strain $\mathrm{B}^{\mathrm{T}}$ contained phosphatidylglycerol (PG) and phosphatidylglycerol phosphate methyl ester (PGP-Me). Phosphatidylglycerol sulfate (PGS) and glycolipids were not detected. The results of biochemical and physiological tests are presented in Table 1 and a detailed species description is presented below. As shown in Table 1, the novel isolate could be readily differentiated from the reference species on the basis of several phenotypic properties.

Chromosomal DNA was extracted and purified as described by Sambrook et al. (1989). The DNA G+C content was determined by using HPLC as described by Mesbah \& Whitman (1989). The 16S rRNA gene was amplified by PCR using a universal primer set as described previously (Baker et al., 2003). Sequencing of the amplified

Table 1. Characteristics that differentiate Halalkalicoccus jeotgali sp. nov. from its closest phylogenetic relative

Species: 1, H. jeotgali sp. nov.; 2, H. tibetensis. +, Positive; -, negative.

\begin{tabular}{|lcc|}
\hline Characteristic & $\mathbf{1}$ & $\mathbf{2}$ \\
\hline $\mathrm{pH}$ range for growth & $6.5-9.0$ & $8.5-10$ \\
Optimal pH & 7.0 & 9.0 \\
Nitrate reduction & - & + \\
Oxidase activity & - & + \\
Utilization of: & & \\
$\quad$ Sucrose & + & + - $^{\star}$ \\
Fructose & - & - \\
Citrate & + & \\
\hline
\end{tabular}

${ }^{\star}$ Negative result is taken from Xue et al. (2005).
$16 \mathrm{~S}$ rRNA gene and phylogenetic analysis were performed according to the methods described by Yoon et al. (2003). DNA-DNA hybridization was performed by the fluorometric method of Ezaki et al. (1989). The 16S rRNA gene sequence of the novel isolate was aligned with 12 reference sequences from the NCBI database (Fig. 1) by using the multiple sequence alignment program CLUSTAL_X (1.8) (Thompson et al., 1997). The phylogenetic relationships of representatives of the genus Halalkalicoccus were determined using the MEGA version 2.1 software program. Distance matrices were determined by following the assumptions described by Kimura (1980). These matrices were used to elaborate dendrograms by using the neighbour-joining method (Saitou \& Nei, 1987). A bootstrap analysis investigating the stability of the trees was performed by obtaining a consensus tree based on 1000 randomly generated trees.

The 16S rRNA gene sequence of strain $\mathrm{B} 3^{\mathrm{T}}$ was compared with the 16S rRNA gene sequences of the reference species belonging to the family Halobacteriaceae. Strain $\mathrm{B}^{\mathrm{T}}$ falls within the species Halalkalicoccus (Fig. 1) and exhibited the highest 16S rRNA gene sequence similarity to Halalkalicoccus tibetensis (98.64\%). DNA sequence similarity, however, between strain $\mathrm{B}^{\mathrm{T}}$ and Halalkalicoccus tibetensis was $7.0 \%$.

On the basis of phenotypic, genotypic and chemotaxonomic comparisons with previously described taxa, we conclude that strain $\mathrm{B}^{\mathrm{T}}$ represents a novel species of the genus Halalkalicoccus, for which the name Halalkalicoccus jeotgali sp. nov. is proposed.

\section{Description of Halalkalicoccus jeotgali sp. nov.}

Halalkalicoccus jeotgali (je.ot.ga'li. N.L. gen. n. jeotgali of jeotgal, a traditional Korean fermented seafood). 
Cells are non-motile cocci with a diameter of 1-1.5 $\mu \mathrm{m}$ and Gram-variable, growing aggregately. Colonies are red and round with a diameter of $0.5-1.0 \mathrm{~mm}$ after incubation for 5 days on the medium, mentioned above, at $37^{\circ} \mathrm{C}$. Cell lysis does not occur in distilled water. Growth occurs in $10-30 \%(\mathrm{w} / \mathrm{v}) \mathrm{NaCl}$, at temperatures ranging from 21 to $50{ }^{\circ} \mathrm{C}$ and at $\mathrm{pH}$ values ranging from 6.5 to 9.0. Optimal conditions are temperatures ranging from 37 to $45^{\circ} \mathrm{C}$, a $\mathrm{pH}$ of 7.0 and $\mathrm{NaCl}$ concentration of $15 \%$. The isolate is catalase-positive, oxidase-negative and does not reduce nitrate to nitrite. Glucose, sucrose, citrate, lactose and acetate can be utilized as sole carbon and energy sources. The polar lipid fraction consists of PG and PGP-Me. PGS and glycolipids were absent. The strain is resistant to the following antibiotics $\left(\mu \mathrm{g} \mathrm{ml}^{-1}\right)$ : bacitracin (50), penicillin (50), ampicillin (50), chloramphenicol (50) and erythromycin (50) and is sensitive to the following antibiotics $\left(\mu \mathrm{g} \mathrm{ml}^{-1}\right)$ : novobiocin (25), anisomycin (25) and aphidicolin (25). The DNA $\mathrm{G}+\mathrm{C}$ content of strain $\mathrm{B}^{\mathrm{T}}$ is $63.2 \mathrm{~mol} \%$.

The type strain, $\mathrm{B}^{\mathrm{T}}\left(=\mathrm{KCTC} 4019^{\mathrm{T}}=\mathrm{DSM} 18796^{\mathrm{T}}=\mathrm{JCM}\right.$ $14584^{\mathrm{T}}=$ CECT $7217^{\mathrm{T}}$ ), was isolated from shrimp jeotgal, a traditional Korean fermented seafood.

\section{Acknowledgements}

The authors are supported by the KRIBB Research Initiative Program and Environmental Biotechnology National Core Research Center (KOSEF: R15-2003-012-02002-0) from the Ministry of Science and Technology (MOST) of the Republic of Korea. We thank Dr J. P. Euzéby for his valuable advice on nomenclature when naming strain $\mathrm{B}^{\mathrm{T}}$.

\section{References}

Baker, G. C., Smith, J. J. \& Cowan, D. A. (2003). Review and re-analysis of domain-specific $16 \mathrm{~S}$ primers. J Microbiol Methods 55, 541-555.

Ezaki, T., Hashimoto, H. \& Yabuuchi, E. (1989). Fluorometric deoxyribonucleic acid-deoxyribonucleic acid hybridization in microdilution wells as an alternative to membrane filter hybridization in which radioisotopes are used to determine genetic relatedness among bacterial strains. Int J Syst Bacteriol 39, 224-229.

Kimura, M. (1980). A simple method for estimating evolutionary rates of base substitutions through comparative studies of nucleotide sequences. J Mol Evol 16, 111-120.

Mesbah, M. \& Whitman, W. B. (1989). Measurement of deoxyguanosine/thymidine ratios in complex mixtures by high-performance liquid chromatography for determination of the mole percentage guanine + cytosine of DNA. J Chromatogr 479, 297-306.

Oren, A., Ventosa, A. \& Grant, W. D. (1997). Proposed minimal standards for description of new taxa in the order Halobacteriales. Int J Syst Bacteriol 47, 233-238.

Purdy, K. J., Cresswell-Maynard, T. D., Nedwell, D. B., McGenity, T. J., Grant, W. D., Timmis, K. N. \& Embley, T. M. (2004). Isolation of haloarchaea that grow at low salinities. Environ Microbiol 6, 591-595.

Saitou, N. \& Nei, M. (1987). The neighbor-joining method: a new method for reconstructing phylogenetic trees. Mol Biol Evol 4, 406-425.

Sambrook, J., Fritsch, E. F. \& Maniatis, T. (1989). Molecular Cloning: a Laboratory Manual, 2nd edn. Cold Spring Harbor, NY: Cold Spring Harbor Laboratory.

Thompson, J. D., Gibson, T. J., Plewniak, F., Jeanmougin, F. \& Higgins, D. G. (1997). The CLUSTAL_X windows interface: flexible strategies for multiple sequence alignment aided by quality analysis tools. Nucleic Acids Res 25, 4876-4882.

Xin, H., Itoh, T., Zhou, P., Suzuki, K., Kamekura, M. \& Nakase, T. (2000). Natrinema versiforme sp. nov., an extremely halophilic archaeon from Aibi salt lake, Xinjiang, China. Int J Syst Evol Microbiol 50, 1297-1303.

Xue, Y., Fan, H., Ventosa, A., Grant, W. D., Jones, B. E., Cowan, D. A. \& Ma, Y. (2005). Halalkalicoccus tibetensis gen. nov., sp. nov., representing a novel genus of haloalkaliphilic archaea. Int J Syst Evol Microbiol 55, 2501-2505.

Yoon, J. H., Kang, S. S., Lee, K. C., Kho, Y. H., Choi, S. H., Kang, K. H. \& Park, Y. H. (2001). Bacillus jeotgali sp. nov., isolated from jeotgal, Korean traditional fermented seafood. Int J Syst Evol Microbiol 51, 1087-1092.

Yoon, J. H., Kang, K. H. \& Park, Y. H. (2003). Halobacillus salinus sp. nov., isolated from a salt lake on the coast of the East Sea in Korea. Int J Syst Evol Microbiol 53, 687-693. 